\title{
Geological structure and coal content of the Ytymdzhinskaya cavity of the Gonamsk coal- bearing region in the South Yakut coal basin
}

\author{
Aleksandr Rukovich ${ }^{1 *}$ \\ ${ }^{1}$ Technical institute (branch) of NEFU in Neryungri, Republic of Sakha (Yakutia), Neryungri, \\ Kravchenko, Russia
}

\begin{abstract}
Southern Yakut coal basin is a huge and reliable base of the high-quality coked and steam coals in the east of the country. The Southern Yakut TPC was begun in the 70-s in the south of Yakutia forming, what predetermined considerable strengthening in this region of exploration works on coal. Now the fields of Neryungri, Elga and certain sites on Denisovsk and Chulmakan fields are developed by an open method. Absence near the operating Neryungri coal mine of the coalfields suitable for opencast mining, and also finite useful lives of the Neryungri field (till 2018-2020) caused expansion of search works on coal on flanks of the basin, directed at identification of the powerful coal layers suitable for development by an open method.
\end{abstract}

\section{Introduction}

The Ytymdzhinskaya cavity is located in the northeastern part of the Gonamsk coal-bearing region in the basin of the river Ytymdzha, the left feeder of the Gonam. The Preytymginskaya depression is located in the cavity's area and is separated from the Gonamsk depression by the ridge Kaltan - Djur on the Gonamsk - Ytymdzhinskaya waterparting [5]. Coal-bearing deposits are developed on the territory of $845,2 \mathrm{sq}$. km, (fig. $1)$.

The geological structure of the cavity is presented by deeply - metamorphosed Archean rock mass, partly deposits of the Upper Proterozoic, Mesozoic deposits and residual quaternary deposits. Intrusive formations of different age, breaking Mesozoic sedimentary cover are also discovered in the region [6].

\section{Materials and methods}

Stratigraphy. The Archean formations, included in the Aldan shield, compose the lower structural level - crystal basement of the exploration area. The formations are presented

*Corresponding author: raul1975@mail.ru 
mainly by intensively interlaid dislocated gneiss and crystal shales, quartzrock; and include calcifer interlayers and lenses, granular limestones, rarely diopside rocks, influenced by the process of ultrametamorphism.

Exposure of the Archean rocks is bad, primary rocks are met rarely in the exposures. As a rule, the Archean contacts with rocks, forming the cavities on faults. The exception is the northern margins of the Ytymdzhinskaya cavity, where exposed thickness of the Archean rocks within the order of $35 \mathrm{~m}$ is the base for the sedimentary complex of the rocks.

Deposits of the Upper Proterozoic have limited spreading, and are developed in the cavity borders. Two strata represent them: terrigene rocks of the Upper Proterozoi and carbon deposits of the Vendian - yudomian suite, overlapping transgressively with angular unconformity on various Archean rocks. In the basin of the river Ytymdzha they build up low limbs of the large-sized synclinal and border mezozoic rock mass deposits mainly from north. These are carbonate shallow sediments of the open sea basin: magnesian limestones, cherty, clay and sandy limestones, marlstones, dolomite limestones.

Mesozoic coal-bearing deposits overlap on the deeply erosional surface of the Archean formations. The Mesozoic deposits thickness includes three lower suites. The upper suites, developed in more deep cavities are not found here.

The Mesozoic deposits section is characterized by terrigene rock composition, being an ordinary full set of rocks from conglomerates and gravelstones to argillites and coals, alternating in less regular sequence of rhythms. Sandstones (50-70\%) represent the basic rock background.

The Mesozoic deposits section is also characterized by multiordinal cyclic process, typical for basins with frequently changing environmental conditions of sedimentation. The sedimentation cycle begins with coarse-grained and ends with fine-grained rocks. Taking into account the cyclic structure of the sedimentation mass and structural communication of drilling prospecting wells in the Ytymdzhinskaya cavity, sediments of the Jurassic period were identified in the Mesozoic deposits composition. Their total exposed thickness is nearly $1100 \mathrm{~m}$. Three suites represent the Mesozoic deposits thickness: the Yukhtinskaya, Duraiskaya and partly, Kabaktinskaya. Upper suites are not found.

The Yukhtinskaya suite $\left(\mathbf{J}_{\mathbf{1}} \boldsymbol{j} \boldsymbol{h}\right)$. The Yukhtinskaya suite deposits spread in a wide stripe on the north of the Ytimdzhinskaya cavity and on the south, they are developed in a narrow stripe. Rock junction with more ancient formations is tectonic.

In the northern part of the cavity in the Yukhtinskaya suite deposits there are seams and lenses of the middle-late Jurassic and early - Cretaceous tabular and subtabular rarely crosscutting intrusive mass including diorite-granodiorite and monzonite-syenitic formations.

The section of the Yukhtinskaya suite deposits begins with gray and light gray medium and coarse-grained arcose and arcose-quartz sandstones with interlayers and lenses of 


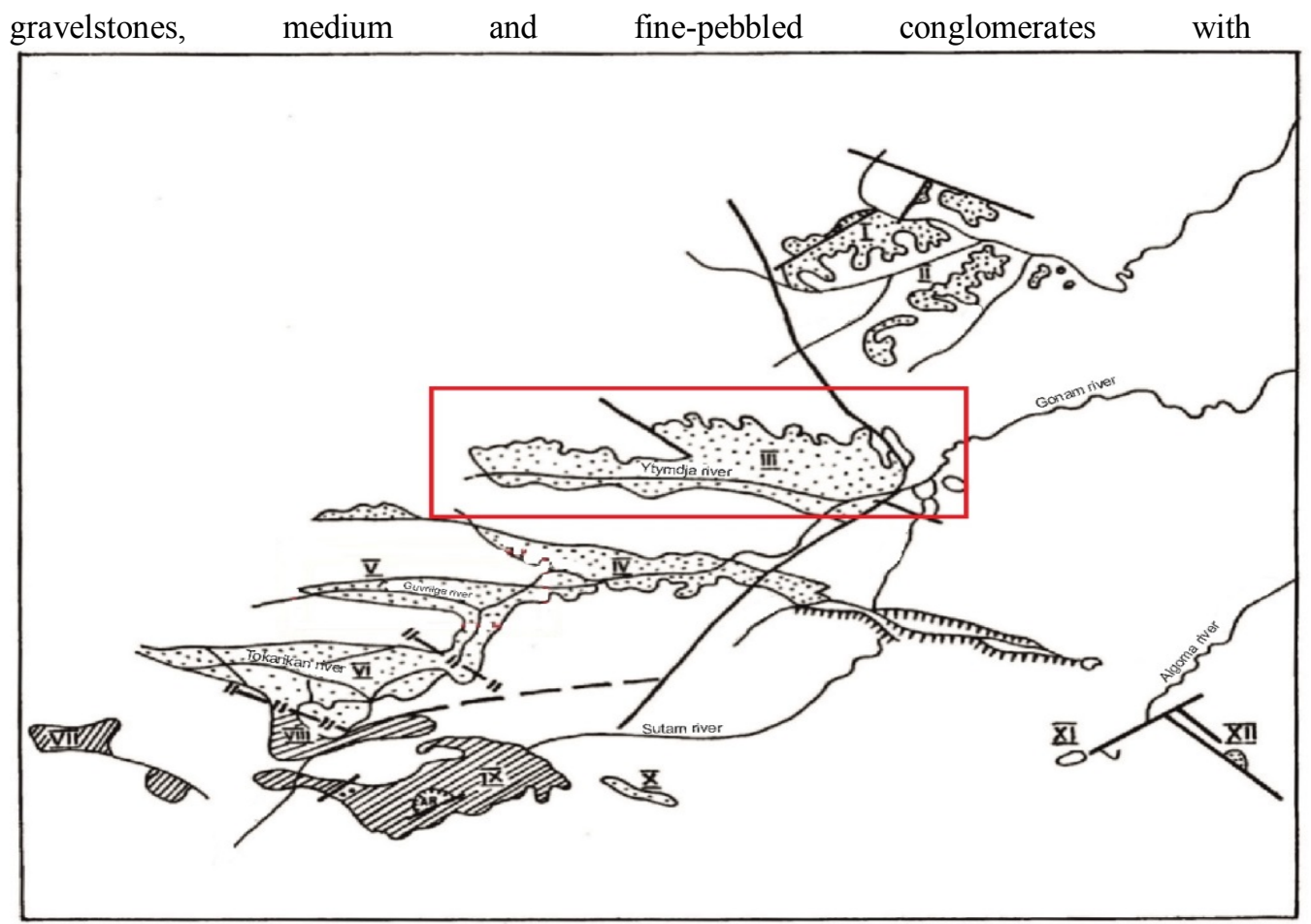

Fig. 1. The arrangement of depressions in the Gonam coal-bearing region

I-Kuranakh-Gynim; II-Gynimo-Semdzhinskaya; III-Ytymdzhinskaya; IV - Gyuskangra-Narulak; VGuivilgra; VI-Tokarikano-Konerkit; VII-Upper Timpton; VIII-Upper-Gonam; IX-Upper Sutama; XUpper-Daurkan; XI-Chekchoy, XII-Awengur

thickness to $3-10 \mathrm{~cm}$. Above the section, the number of coarse-grained material in the sandstones decreases. Thin interlayers of coarse and fine-grained dark-gray siltstones emerge. The Yukhtinskaya suite thickness varies from 230 to $240 \mathrm{~m}$.

The Duraiskaya suite $\left(\mathbf{J}_{\mathbf{2}} \boldsymbol{d} \boldsymbol{r}\right)$. The deposits of the productive Duraiskaya suite conformably overlie everywhere on the Yukhtinskaya suite rocks, especially in the central and northern parts of the cavity [4]. At the base of the suite there are series of coarse and medium-grained sandstones with thickness of up to 10-15 meters including thin interlayers and lenses (to $0,5-1,0 \mathrm{~m}$ ) of fine-pebbled conglomerates and gravelstones. The middle part of the suite is composed mainly of gray and dark-gray series of fine-grained sandstones, alternating with fine and coarse - grained siltstones and medium-grained sandstones. The character of stratification is mostly low wave and horizontal, confined to aleurolitic series, sandstones are characterized by cross-wave and wave bedding. The upper part of the Duraiskaya suite section is composed mainly of fine-grained sandstones with light-gray colour, alternating with interlayers of dark-gray siltstones. Ten coal seams and coal shows were discovered in the formation section. Seven of the coal beds have thickness of $0,7 \mathrm{~m}$ and more. The suite's thickness is estimated at 330 meters.

The Kabaktinskaya suite $\left(\mathbf{J}_{3} \boldsymbol{\kappa} \boldsymbol{b}\right)$ conformably overlies on the rocks of the Duraiskaya formation and is exposed on the whole territory of the cavity. The formation section begins with alternation of the coarse-grained material (medium and coarse- grained sandstones) [7]. Overall, the exposed part of the formation section is presented by thick series $(20-30 \mathrm{~m})$ of coarse-grained sandstones with light-gray colour, weakly fractured and unstratified with interlayers of fine-grained light-gray sandstones and fine and coarse-grained dark-gray siltstones, weakly fractured with irregular horizontal stratification. More than 25 seams and 
coal shows were identified in the exposed formation section. 23 of the seams have thickness from $0,7 \mathrm{~m}$ and more in separate seam intersections. The exposed thickness (partial) of the Kabaktinskaya formation is estimated at $550 \mathrm{~m}$. Thus, the total exposed thickness of the Mesozoic deposits in the Ytimdzhinskaya cavity is about $1120 \mathrm{~m}$. The quaternary deposits (Q) are also developed everywhere as on the area of the Guvilgrinskaya cavity and are presented by alluvial, diluvial-solifluction and lacustrine - boggy formations.

Tectonics. The Ytymdzhinskaya cavity, bordered from the south by regional SouthYtimdzhinsk fault is a large asymmetric synclinal with low north limb and steep southern limb, cut by the fault. The cavity is oriented in the East-West direction; its sizes are 130x 30 $\mathrm{km}$. The most sunk part of the cavity's foundation is near the South - Ytymdzhinsk regional fault and according to the local geophysic investigations is $0,5-0,7 \mathrm{~km} \mathrm{[5]}$.

From the north, the Ytymdzhinskaya cavity is bounded by areal limits of the Proterozoic and Mesozoic sedimentary rocks. Weakly dislocated rocks zone is situated in the Northern and middle parts of the cavity. Here the thickness has simple monoclonal structure frequently complicated by folds, small sized folds of east-west trending [1]. It is possible to observe small interformational movements in the seams, sometimes causing redistribution of the coal material. In this case, in the soil and bed top, well-marked polish faults can be identified. Flexure bends in contrast to linear monoclonal bedding indicate block structure of the basement. They come amid parallel rock fracturing. The bends confirm the hypothesis about long-lasting existence of faults in the basement. Throughout most part of the Ytymdzhinskaya cavity area, low Mesozoic rocks at an angle of $4-10^{\circ}$ (to $20^{\circ}$ ) are inclined to the south, to the cavity's center [3].

The zone of rocks with complex dislocation - the southern limb of the synclinal is situated on the right bank of the Ytymdzha. It is narrower than the northern limb, is steep and located in downdip block, to the south of which ridge fault is emerging. The Southern limb width is $1,5-3,0 \mathrm{~km}$, it has complex dislocation and is complicated by smaller folds. Dip angles of the second order folds limbs reach 50 and more degrees. Disjunctive faults of the rocks are presented by throws, faults, break-thrusts with steep dip angles. Rather a unique feature of the cavity is intensive show of the Mesozoic magmatism, as a result of which, the Jurassic deposits are broken by numerous subalcalic intrusive sheets, which alternate with sedimentary rocks [9].

\section{Results and discussion}

Coal-bearing capacity. In the coal-bearing thickness section, studied by the wells, seams and interlayers of coal are almost everywhere (the Duraiskaya and Kabaktinskaya formations) but their distribution both in the section and on the area are uneven [2]. Totally, there are 37 coal seams including more than 25 seams with working thickness $(0,7 \mathrm{~m}$ and more) in the exposed coal-bearing thickness. Total thickness of all coal seams and interlayers of profile 1-1 is more than $40 \mathrm{~m}$, and of working seams $-25 \mathrm{~m}$.

In lithologic and stratigraphic section, as was already mentioned, letter and cipher symbols were assigned. The letter symbol represents formation's name and the cipher symbol - counting number of the seam in the formation's section (downwards). Characteristics of coal-bearing capacity of the formations is given below [8]:

The Yukhtinskaya formation is almost coal-free.

The Duraiskaya formation. In the formation section more than 12 coal shows with thickness from $0,20 \mathrm{~m}$ to $6,5 \mathrm{~m}$ (well 16, seam D15) were discovered. Four of them have working thickness $(0,7 \mathrm{~m}$ and more), the seams structure is complex and presented mainly by one interlayer. According to their thickness, the seams mainly belong to the category of thin and median. From the five indexed seams of the Duraiskaya formation, the seam D15 is more continuous both in its section and in thickness. 
The Kabaktinskaya formation has more than 25 coal shows and eight of them have working values of thickness from 0,7 and more. The seams structure is complex and is presented by one or two interlayers. Coal seams $\mathrm{K}_{13}, \mathrm{~K}_{8}, \mathrm{~K}_{6}, \mathrm{~K}_{4}$ represent the most practical interest as they are more continuous in section and have working values of thickness. $K_{8}$ is the most continuous seam. The seams belong to the category of thin and median in their thickness, average thickness is $1,3 \mathrm{~m}$.

\section{Conclusion}

The description of the indexed seams of the formations is given in Table 1 .

As a result, it is obvious that the most coal replete is the middle part of the section. Extraction of the coal seams of the section's middle part will demand additional geological exploration.

Table 1. Basic parameters of the indexed coal seams of the Ytymdzhinskaya cavity

\begin{tabular}{|c|c|c|c|c|c|c|c|}
\hline \multirow[b]{2}{*}{ Suite } & \multirow[b]{2}{*}{$\begin{array}{c}\text { Sea } \\
\mathrm{m} \\
\text { inde } \\
\mathrm{x}\end{array}$} & \multicolumn{4}{|c|}{ Basic parameters } & \multirow[b]{2}{*}{$\begin{array}{l}\text { Limits of mining } \\
\text { plies thickness } \\
\text { variation From - } \\
\text { to Average } \\
\text { thickness } \\
\text { (a number of } \\
\text { intersectings) }\end{array}$} & \multirow[b]{2}{*}{$\begin{array}{l}\text { Bed structure } \\
\text { (a number of } \\
\text { separation } \\
\text { seams) }\end{array}$} \\
\hline & & $\begin{array}{c}\text { Total } \\
\text { number of } \\
\text { wells } \\
\text { penetration }\end{array}$ & $\begin{array}{c}\text { Number of } \\
\text { penetrations } \\
\text { with } \\
\text { thickness to } \\
0,7 \mathrm{~m} / \text { zero } \\
\text { data }\end{array}$ & $\begin{array}{c}\text { Number of } \\
\text { penetrations } \\
\text { with } \\
\text { thickness to } \\
0,7 \mathrm{~m} \text { and } \\
\text { more }\end{array}$ & $\begin{array}{c}\text { Seam } \\
\text { continu } \\
\text { ity } \\
\text { coeffici } \\
\text { ent }\end{array}$ & & \\
\hline 1 & 2 & 3 & 4 & 5 & 6 & 7 & 8 \\
\hline \multirow{6}{*}{$\begin{array}{c}\text { Durais } \\
\text { kaya }\end{array}$} & $\mathrm{D}_{19}$ & 12 & $5 / 6$ & 1 & 0,1 & $\frac{0-0,86}{0,20(12)}$ & $\begin{array}{c}\text { Complicated } \\
1 \\
\end{array}$ \\
\hline & $\mathrm{D}_{15}$ & 12 & $0 / 0$ & 12 & 1,0 & $\frac{0,84-6,0}{1,80(12)}$ & $\begin{array}{c}\text { Complicated } \\
1\end{array}$ \\
\hline & $\mathrm{D}_{14}$ & 9 & $1 / 7$ & 1 & 0,1 & $\frac{0-0,86}{0,13(9)}$ & $\begin{array}{c}\text { Complicated } \\
1 \\
\end{array}$ \\
\hline & $\mathrm{D}_{13}$ & 9 & $1 / 5$ & 3 & 0,33 & $\frac{0-1,44}{0,44(9)}$ & $\begin{array}{c}\text { Complicated } \\
1 \\
\end{array}$ \\
\hline & $\mathrm{D}_{11}$ & 8 & $1 / 5$ & 2 & 0,25 & $\frac{0-0,78}{0,23(8)}$ & Simple \\
\hline & $\mathrm{D}_{7}$ & 7 & $1 / 4$ & 2 & 0,29 & $\frac{0-1,20}{0,39(7)}$ & $\begin{array}{c}\text { Complicated } \\
1-3 \\
\end{array}$ \\
\hline \multirow{11}{*}{$\begin{array}{l}\text { Kabakt } \\
\text { inskaya }\end{array}$} & $\mathrm{K}_{14}$ & 8 & $5 / 2$ & 1 & 0,12 & $\frac{0-1,30}{0,45(8)}$ & $\begin{array}{c}\text { Complicated } \\
2 \\
\end{array}$ \\
\hline & $\mathrm{K}_{13}$ & 11 & $1 / 0$ & 10 & 0,91 & $\frac{0,36-3,03}{1,79(11)}$ & $\begin{array}{c}\text { Complicated } \\
1-2\end{array}$ \\
\hline & $\mathrm{K}_{10}$ & 13 & $12 / 0$ & 1 & 0,1 & $\frac{0,30-1,02}{0,50(13)}$ & $\begin{array}{c}\text { Complicated } \\
1 \\
\end{array}$ \\
\hline & $\mathrm{K}_{8}{ }^{\mathrm{B}}$ & 13 & $1 / 5$ & 7 & 0,54 & 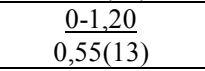 & $\begin{array}{c}\text { Complicated } \\
1-3 \\
\end{array}$ \\
\hline & $\mathrm{K}_{8}$ & 13 & $0 / 0$ & 13 & 1,0 & $\frac{0,92-1,68}{1,27(13)}$ & $\begin{array}{c}\text { Complicated } \\
1 \\
\end{array}$ \\
\hline & $\mathrm{K}_{6}$ & 14 & $3 / 1$ & 10 & 0,71 & $\frac{0-2,97}{0,91(14)}$ & $\begin{array}{c}\text { Complicated } \\
1\end{array}$ \\
\hline & $\mathrm{K}_{5}$ & 15 & $7 / 5$ & 3 & 0,20 & $\frac{0-1,82}{0,50(15)}$ & $\begin{array}{c}\text { Complicated } \\
1 \\
\end{array}$ \\
\hline & $\mathrm{K}_{4}{ }^{\mathrm{B}}$ & 15 & $0 / 11$ & 4 & 0,27 & $\frac{0-1,50}{0,28(15)}$ & $\begin{array}{c}\text { Complicated } \\
1 \\
\end{array}$ \\
\hline & $\mathrm{K}_{4}$ & 16 & $2 / 5$ & 9 & 0,56 & $\frac{0-4,78}{1,26(16)}$ & $\begin{array}{c}\text { Complicated } \\
1-3 \\
\end{array}$ \\
\hline & $\mathrm{K}_{3}$ & 16 & $2 / 9$ & 5 & 0,31 & $\frac{0-1,32}{0,43(16)}$ & $\begin{array}{c}\text { Complicated } \\
1-2 \\
\end{array}$ \\
\hline & $\mathrm{K}_{1}$ & 15 & $4 / 10$ & 1 & 0,1 & $\frac{0-1,20}{0,21(15)}$ & Simple \\
\hline
\end{tabular}




\section{References}

1 Verkhovtsev A N Lukyanova Zh K Carrying out specialized works on tracking coal seams with the help of deciphering the AFS in the Gonam coal-bearing area of the South Yakut basin. The report for 1992-1996. Yakutsk. (1996).

2 Zaliznyak M I Report on prospecting works in the southern part of the Gonam area for 1988-1996. Funds of the State Humanitarian University "Yuzhyakutgeologiya". (1997).

3 Minakov V S Verevkin N I Report on the group geological survey and geological study of the m-ba 1: 50000 on the territory of sheets $0-51-132-\mathrm{B}, \mathrm{G} ; 133-\mathrm{AB} ; 134-\mathrm{AB}$; 0 51-121,122 (Guvilgra gold-bearing area on the works of the Melemken party for 1981-87). Funds of "Yuzhyakutgeologia".

4 Utrobin D V Geological structure and minerals of the Upper Sutama gold-bearing area. Funds "Yuzhyakutgeologia". (1989).

5 Shiryaev V P Borzykh S D Report on the topic: Structural-tectonic map of the South Yakutian basin 1:500000 with maps-inserts 1:50000 for prospective plots. Funds of "Yuzhyakutgeologia". (1981).

6 Cherepovsky V F Coal base of Russia. Coal basins and fields/hl. Geoinformark, T.5. Book 2. 638 p. (1999).

7 Hvorostina A A Potentsial of a subsoil of a frame of the Southern Yakut coal field Neryungri Publishing house Tekhn. in-that SVFU. 238 p. (2012).

8 Mineral resources of the coal industry of Russia. In 2 volumes. 2 (regions and pools). Moskow publishing house. state. mountains. un-that. 448 p. (1999).

9 Cherepovsky V F Coal basins of the region of the Baikal-Amur Mainline. Moskow, Nedra. 157 p. (1984). 